\title{
Onset of Effect, Changes in Airflow Obstruction and Lung Volume, and Health-Related Quality of Life Improvements with Benralizumab for Patients with Severe Eosinophilic Asthma: Phase IIIb Randomized, Controlled Trial (SOLANA) [Corrigendum]
}

\author{
Panettieri RA Jr, Welte T, Shenoy KV, et al. J Asthma \\ Allergy. 2020;13:115-126.
}

The authors have advised that the symbol shown on page 124 , discussion section, left column, line 5 " $\geq 20 \%$ " should read " $<20 \%$ ". The authors apologize for this error.

\section{Publish your work in this journal}

The Journal of Asthma and Allergy is an international, peer-reviewed open-access journal publishing original research, reports, editorials and commentaries on the following topics: Asthma; Pulmonary physiology; Asthma related clinical health; Clinical immunology and the immunological basis of disease; Pharmacological interventions and new therapies. The manuscript management system is completely online and includes a very quick and fair peer-review system, which is all easy to use. Visit http://www.dovepress.com/testimonials.php to read real quotes from published authors. 